\title{
BUILDING STUDENTS' CHARACTER THROUGH PROPHETIC EDUCATION AT MADRASA
}

\section{Citra Putri Sari}

Universitas Islam Negeri (UIN) Sunan Ampel Surabaya

Jl. Ahmad Yani No.117, Wonocolo, Kota Surabaya, Jawa Timur, Indonesia, 60237

Email: alcitraputri@gmail.com

\section{Husniyatus Salamah Zainiyati}

Universitas Islam Negeri (UIN) Sunan Ampel Surabaya

Jl. Ahmad Yani No.117, Wonocolo, Kota Surabaya, Jawa Timur, Indonesia, 60237

Email: husniyatus@yahoo.com

\section{Rudy Al Hana}

Universitas Islam Negeri (UIN) Sunan Ampel Surabaya

Jl. Ahmad Yani No.117, Wonocolo, Kota Surabaya, Jawa Timur, Indonesia, 60237

Email: rudy.alhana@uinsby.ac.id

Received: 11, 2019. Accepted: 06, 2020. Published: 06, 2020

\begin{abstract}
Several cases of juveniles have to some extent dominated mass media news recently and this worrying reality is contradictory to the purpose of education that teenagers are expected to achieve. In an attempt to solve this problem, various efforts have been made by educators and one of them is to promote prophetic-based education. This study was aimed at investigating prophetic education at Madrasa Muallimin/Muallimat (MMA) Bahrul Ulum Tambak Beras, Jombang. This research is qualitative descriptive using models of Miles and Huberman analyses. The data collected were analyzed through several steps namely reduction, presentation, and data verification. The results showed that the prophetic education was applied in MMA through internalizing Islamic values for students in their learning process. When it comes to internalizing values, MMA referred and addressed the local culture to cultivate for students. This process has been built since the establishment of MMA so that it has built students' character which in turn gradually form the identity of the MMA among the society where it exists.
\end{abstract}

Keywords: Character Building, Madrasa, Prophetic Education

\begin{abstract}
ABSTRAK
Beberapa kasus remaja sampai taraf tertentu mendominasi berita media massa baru-baru ini dan kenyataan yang mengkhawatirkan ini bertentangan dengan tujuan pendidikan yang dibarapkan dicapai oleb remaja. Dalam upaya untuk memecabkan masalah ini, berbagai upaya telah dilakukan oleh pendidik dan salah satunya adalab untuk. mempromosikan pendidikan berbasis kenabian. Penelitian ini bertujuan untuk menyelidiki pendidikan kenabian di Madrasah Muallimin / Muallimat (MMA) Babrul Ulum Tambak Beras, Jombang. Penelitian ini adalah deskriptif kualitatif dengan menggunakan model analisis Miles dan Huberman. Data yang dikumpulkan dianalisis melahi beberapa langkah yaitu reduksi, presentasi, dan verifikasi data. Hasil penelitian menunjukean bahwa pendidikan kenabian diterapkan dalam MMA melalui internalisasi nilai-nilai Islam untuk siswa dalam proses belajar mereka. Ketika membicarakan proses menginternalisasi nilai-nilai, $M M A$ merujuk dan berbicara tentang budaya lokal untuk. dikembangkan bagi siswa. Proses ini telah dibangun sejak pembentukan MMA sehingga telah membangun karakter siswa yang pada giliranny secara bertahap membentuk. identitas $M M A$ di antara masyarakat di mana ia berada.
\end{abstract}

Kata Kunci: Pembangunan Karakter, Madrasah, Pendidikan Profetik. 


\section{INTRODUCTION}

The last few years, moral problems seem to be the main topic that appears both on print and electronic media. Like an immorality, criminality, and corruption case. As data released by the central statistic based on Podes (Potensi Desa/Village Potential) data, the number of villages that occurred in mass conflict during 2011-2018 of the number about 2.500 villages in 2011 increased to 2.700 villages in 2014, and re-increased to about 3.100 villages in the year 2018 . Likewise, the data obtained from Susenas, that the percentage of the population that has been victims of crime during the period 2016-2018 also shows a fluctuating pattern. This data is taken through three main approaches to criminal statistics, approach to perpetrators, victims and cantilties. The data is obtained from two main sources of criminal statistics, namely administrative based data compiled by Polri (Polisi Republik Indonesia/National Police) and surveys based data sourced from Susenas (Survei Sosial Ekonomi Nasional/National SocioEconomic Survey) and Podes data produced by BPS (Badan Pusat Statistik/Central Statistics Agency, 2019).

From the data exposure above, it clearly demonstrates the implications of degradation to the moral of the nation. In the sense there has been disobedience to the rules that occur in the community that is done by a group of people or individually. The urbanization factor is one of the main triggers of increased criminality, resulting in moral decadence. One of the implications of this urbanization factor is the increasing number of people who flock to the city in hopes of getting a better life. But low skills sometimes become a result of the emergence of poverty, resulting in unemployment cases that cause an increase in cases of criminality. According to Lickona quoted by Cahyo in his journal, mention there are 10 symptoms of moral degradation, 1) violence and acts of Anarchy, 2) theft, 3) fraudulent action, 4) waiver of the prevailing rule, 5) brawl, 6) intolerance, 7) improper use of language, 8) premature sexual maturity and misappropriation, 9) Self destruction, and 10) drug abuse (Cahyo, 2019).

Seeing from the symptoms expressed by Lickona, moral decadence seems to have also entered the educational institution. The occurrence of moral decadence in a nation certainly has a relationship with activities that are processed through school. Because the crisis of education everywhere is always the same intensity as the moral crisis that exists in society (Frye, Lee, \& LeGette, 2002). When viewed from the formulation of educational goals, the output produced by the education sector should be students with a complete morality. As the general purpose of Education according to Dewey in Purwanto, namely to shape humans into good citizens (Purwanto, 1991). Whereas the goal of national education in the National Education System Law No. 20 of 2003 is developing the potential of students to become human beings who believe and fear God Almighty, have good character, be healthy, knowledgeable, capable, creative, independent, and become citizens who are democratic and responsible. The formulation of the aim of education is not much different from the aim of Islamic education which is inseparable from the purpose of human life in Islam, namely creating a personal servant of Allah who is always devoted, and can achieve life in this world and the hereafter (Azra, 2012).

But ironically, there is a contradictory gap between educational practices and the character quality of students. Development of the nation's character that has been pursued in various forms, until now has not been implemented optimally. Even the condition of moral decadence actually shows the low achievement of moral competence that is processed through the educational process at school. This is reflected in the increasing number of criminal acts, human rights violations, and some of the despicable acts committed by school children (Setiawan, 2013). 
Like the AU case, one of the junior high school students in Pontianak, West Kalimantan who became a victim of the beatings of high school students on March 29, 2019 (Ambarawati, 2019). Another case that was viral was the case of NF, a 15 -year-old middle school girl who viciously killed a 5-year-old child and was hidden, in March 2020 (Bima, 2020). These two cases are just a few of the thousands of cases that occur every day. Even cases like this seem to be the main headline in the media. Students who come from millennial generation are indeed very close to ICT matters, so there is a need for a strong foundation in the spiritual and moral realms (Ma'rufah, et. al., 2020). In addition to spiritual and moral foundations, in journals Asbari, et. al. also explained that a person's character is strongly influenced by Genetic Personality and Authoritative Parenting Style (Asbari, et. al., 2020). But this study lacks depth in the discussion of character. Therefore, the last few years' character education is being actively promoted as a strong foundation on students.

Moral education or more familiar with the term character education can be applied in two ways, namely by conceptual character education and character education tucked in a hidden curriculum. However, the effectiveness of the conceptualized character education implementation will tend to be limited. But this journal is not accompanied by in-depth observations in the field (Meindl, Quirk, \& Graham, 2018). The pursuit of character education can be implemented in many ways. As research in the journal Watson that character education can be pursued through example, as Linda Zagzebski's theory states that exemplary is a guide in moral training (Watson, 2019). This concept is in line with the concept of character education in the time of the prophet Muhammad SAW. The Messenger of Allah was sent as uswat al hasanah and rabmatan lil 'alamin (Nizar, 2007). As contained in Q.S Al-Ahzab: 21 concerning the Prophet as a role model. In the interpretation of Jalalain, the good role model is interpreted as things that can be followed, such as in fighting and the determination and patience of the Prophet Muhammad. it also includes the educational process that was practiced by the Prophet in his time (Al Mahalli dan As Suyuthi, 2007).

Rasulullah educates humans not only to transfer material, but also to integrate the process of science transformation, internalizing the values of spiritualism and emotional guidance. Given the effort and success of the Prophet in educating humans, the concept of prophetic education emerged. This prophetic education with educational processes and values that aim to get closer to Allah SWT (Ismail, 2013). Actually research on prophetic education has been widely reviewed. Like the research conducted by Arifuddin on the concept of prophetic education. but in this study conceptual prophetic education is explained (Arifuddin, 2019). Or research conducted by Judges regarding the implementation of prophetic education in MTs Bululawang. This study only reviews the implementation of prophetic education without the review of the impacts resulting from prophetic education (Hakim, 2017). Furthermore, in this study using prophetic education as a construction in the implementation of character education is certainly able to remove education from the problems of moral disintegration which currently infect many of its students.

From the results of previous studies, this study will complement the Asbari research in 2020 , with a deeper review of the formation of students' character through prophetic education construction. In addition, this study improves the research methods used by Meindl, Quirk, and Graham in 2018 which do not use in-depth observations in their research. Strengthening Watson's research in 2019 that character building can be done through role models. As well as completing the research of Arifuddin, (2019) and Judge 2017 in reviewing prophetic education accompanied by field observations and reviews of the impacts produced by prophetic education. These weaknesses will be answered in this study, with the formulation, namely: (1) How is the construction of prophetic education in the Madrasah Muallimat Muallimat 6 year Bahrul Ulum Tambakberas Jombang ?. (2) How is the formation 
of character through the construction of prophetic education in the Madrasah Muallimin Muallimat 6 year Bahrul Ulum Tambakberas Jombang?

\section{METHOD}

This research uses a qualitative approach. The location of this research is Madrasa Muallimin Muallimat bahrul Ulum Tambakberas Jombang. There are 7 informants in this study with the following categories:

Table 1. Informant Criteria

\begin{tabular}{|c|c|c|c|}
\hline No & Informant & Male/Female & Criteria \\
\hline 1 & $\mathrm{AR}$ & Male & $\begin{array}{l}\text { AR informant is the deputy head of the madrasah, who is } \\
\text { responsible for holding all matters relating to Madrasah } \\
\text { Aliyah Muallimin Muallimat. }\end{array}$ \\
\hline 2 & MS & Male & $\begin{array}{l}\text { MS informant is one of the educators teaching general } \\
\text { subjects, namely Indonesian Language. In the } \\
\text { management structure, MS is responsible as the student } \\
\text { council assistant. MS is also one of the alumni of this } \\
\text { madrasa. }\end{array}$ \\
\hline 3 & $\mathrm{AB}$ & Male & $\begin{array}{l}\mathrm{AB} \text { informant is also one of the educators who hold } \\
\text { English subjects. In terms of education, } \mathrm{AB} \text { graduated } \\
\text { with a master's degree. In addition to teaching at this } \\
\text { madrasa, } \mathrm{AB} \text { also teaches at several madrassas around the } \\
\text { Bahrul Ulum foundation. }\end{array}$ \\
\hline 4 & $\mathrm{AF}$ & Male & $\begin{array}{l}\text { RF informant is one of the educators who has only been } \\
\text { educating in this madrasa for } 4 \text { years. Aside from being an } \\
\text { educator, he can also be considered the right-hand man of } \\
\text { the head of madrasah. }\end{array}$ \\
\hline 5 & $\mathrm{DM}$ & Female & $\begin{array}{l}\text { DM informant is one of the educators who has been } \\
\text { serving Muallimin Muallimat for almost } 5 \text { years. DM } \\
\text { initially became a library employee due to a shortage of } \\
\text { library guards. It's only been one year since DM started } \\
\text { teaching. }\end{array}$ \\
\hline 6 & SZ & Female & $\begin{array}{l}\text { SZ informant is one of the students who is currently } \\
\text { sitting in grade } 5 \mathrm{MMA} \text { and moved up to grade } 6 . \mathrm{SZ} \text { is } \\
\text { from Nganjuk and currently resides in PPP al } \\
\text { Fathimiyyah. SZ is a graduate of MTsN and is admitted to } \\
\text { the Muualimat Madrasa accepted in grade } 2 \text {. }\end{array}$ \\
\hline 7 & $\mathrm{UA}$ & Male & $\begin{array}{l}\text { UA informant is one of the alumni. UA currently resides } \\
\text { in Nganjuk and is a trader. At the time of school UA was } \\
\text { domiciled in the Muhibbin lodge. During the UA school } \\
\text { was one of the organizing members who was quite active } \\
\text { in several activities held at the madrasah. }\end{array}$ \\
\hline
\end{tabular}

In collecting data, researchers used field observation techniques for 3 months. In this observation technique the researcher involved himself in several activities in Madrasah and observed every detail of the activity. Starting from teaching and learning activities to extracurricular activities held by madrasah. Then the researchers also used interview techniques with the indept interview method. In addition, several documents related to the research title were also documented. The data obtained were then analyzed using the Miles and Huberman model, namely reduction, presentation, and data verification. In the interactive model, the three types of analysis activities and data collection activities are cyclical and interactive processes (Idrus, 2009). To interpret the meaning of transcript data, 12 tactics are also used according to Miles and Huberman (Cohen, et. al., 2007). While in the test of the 
validity of the data the author uses triangulation, namely triangulation of sources, techniques and time triangulation (Sugiyono, 2015). In this case, data from interviews with school principals are crossed with interviews with teachers, students, and alumni of volunteers. While technical triangulation is done by crossing the data between the results of interviews, observations and documentation.

\section{RESULTS AND DISCUSSION}

\section{Construction of Prophetic Education in Madrasah Muallimin Muallimat 6 Years Bahrul Ulum Tambakberas Jombang}

The implementation of prophetic education in Madrasah Muallimin Muallimat is illustrated in 7 components of education, namely first, prophetic educators who focus on the personality factors of religious educators. As is the case with the entrepreneurial personality. Aside from the religious side, educators at MMA also prioritize scientific professionalism. In MMA science is not only seen from the achievements of the last diploma of education. But more to see from the side in the mastery of subjects. Second, more specific prophetic goals. In addition to seeing students as individuals as individuals, the aim of prophetic education also views the position of students as creatures that have the Essence that must be worshiped and views the position of students as socially living beings. Here it means that the learner has the portion of habluminallah (the relationship between the individual and God) and habluminannas (the relationship between the individual and other individuals) in a ballance (balanced). In addition, the goals of prophetic education are also more predictive and visionary. That is an effort to make students competent in forming the ideal social community in society. Namely being a person who is able to create a society that is polite, civilized and cultured. Third, prophetic educational material that contains 3 main points, namely amar ma'ruf, nahi munkar, and tu'minuna billah which are drawn from the learning material used by Madrasah. Fourth, prophetic students viewed in terms of their nature. Based on the understanding of nature possessed by these students, the madrasah prepares several extracurricular activities in order to develop the potential of students.

Fifth, the prophetic education method used in this madrasah is the lecture method which is accompanied by exemplary and also accompanied by the inculcation of religious values to students. There are several uniqueness in the process of using the lecture method in this madrasah, namely the use of the lecture method tends to hit and shape the personality of students. Then the lecture method was applied also accompanied by the teacher's example. For this reason, it gives its own impact on the personality and character of students. Sixth, the media used in this madrasah are simple media accompanied by the dominant role of educators so that they can shape the character of students. Seventh, evaluation of prophetic education in this madrasah is an evaluation covering the quality of understanding, mastery of the material, intelligence and skills which are carried out through several written and oral examinations and some memorization.

The implementation of prophetic education in this madrasah is categorized as an interconnective integrative prophetic education model. This is due to the absence of a dichotomy between general education and religious education. Although there are differences in weights in the presentation of the curriculum, it does not mean madrasah treat different subjects with small weights. The difference in weight distribution is only limited to classification, not a dichotomization. The interconnective integrative attitude can be seen in three ways, namely, first, the same treatment given by madrasah to all educators, both those who support general subjects and religious subjects. Second, all subjects are tested without exception. Even now, general subjects are tested as material on students' practical teaching examinations. Even the general subject, namely Indonesian, is one of the subjects that is used 
as a consideration for class advancement and student graduation. It is assumed that when students will be able to master religious subjects, but are unable to use good language instruction, it will be in vain. For this reason, Indonesian is used as the main subject for determining students' graduation and graduation. Third, the same attitude, namely the attitude of respect and obedience is also shown by students to all educators, regardless of the subjects being taught.

\section{Formation of Character through Construction of Prophetic Education in Madrasah Muallimin Muallimat 6 Years Bahrul Ulum Tambakberas Jombang}

When researchers asked about the implementation of character education to the informants, it actually has been formed long ago. Even the implementation of character education is not there because of moral decadence factors as character education in general, which began to be echoed when morals began to appear the decline. But it has been around since this madrasah was founded. The character values have been implemented and used as part of the madrasah. The character is already entrenched and cannot be separated from the madrasah itself.

This madrasah is able to maintain that culture because the leader always gives an overview of madrasa culture. This was also done by the previous leader. So that the culture remains attached to the madrasa and has never been eroded by time. So that the environment with strong character has been formed as the identity of Madrasah. Therefore, without the growth process of the mindset of all elements of education stakeholders, they have automatically been carried away by culture so that the character in this Madrasah becomes a strong character.

The process of character education in this academy is formed through internalizing values and modeling with prophetic education construction. The intention is to instill values in the learning process and the role models of each educator component. So that formed a strong character from students. The prophetic education in this madrasa is based on culture which has been able to form an inherent character and become the madrasa's identity. The impact of prophetic education produces 6 characters, namely caring, responsibility, perseverance, courage, integrity and discipline. This can be illustrated through the following chart:

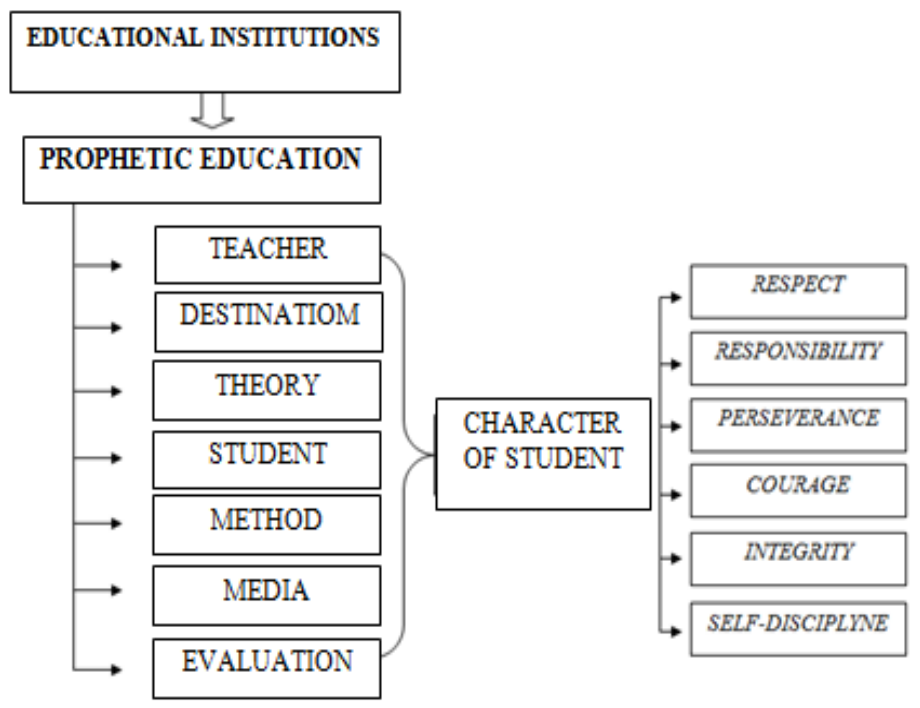

Figure 1. Character Building through Prophetic Education Construction 
The construction of prophetic education at the Madrasah Muallimin Muallimat 6-year Bahrul Ulum Tambakberas Jombang has been reflected in each of its components. Like the educator component. This consideration from the scientific side and religious aspects of the educator reinforces Ismail's theory in the book of ta'lim al muta'alim (Ismail, t.t.). Then in terms of objectives, which have specific and predictive goals. This reinforces the research of (Diniaty, 2013; Zadjuli, 2007). In addition, this goal is also in line with the description of prophetic education (Shofan, 2004; Roqib, 2011). Furthermore, in terms of prophetic education material in MMA which is focused on 3 aspects of learning material that includes amar ma'ruf, nahi munkar, and tu'minuna billah. This is in line with Kuntowijoyo's theory which is sourced from QS. Ali Imran: 10 (Kuntowijoyo, 2007). Then students, where students are seen in terms of the nature they have. The nature that children carry from birth has potential traits, requiring human efforts in the development process to be actual and factual. Departing from the fitrah award is then applied with several development activities to the potential of students. This is certainly in line with the Prophet's hadith narrated by Imam Buhkori and Muslim Imam about human nature. It also strengthens the research of Moh. Roqib and Suharto's theory (Roqib, 2011; Suharto, 2011).

Then in terms of learning methods, MMA is more dominated by the lecture method with the inclusion of educators. This reinforces the research of Zurqoni et. al., (2018) that the integration of role models in teaching and learning is indeed very influential. (Zurqoni, et. al., 2018). This prophetic at MMA is more dominant in the role of educators in Wahidin's research, the role of educators is also categorized as the media, namely in the form of exemplary, commands, advice and so forth (Wahidin \& Syaefuddin, 2018). Making the example as the main media is certainly more able to strengthen the character of the students, this strengthens Watson's research, quoting from Linda Zagzebsky's expression (Watson, 2019). The final component is evaluation of prophetic education. Evaluation of prophetic education in MMA evaluation includes the quality of understanding, mastery of the material, intelligence and skills, as well as measuring and assessing the moral values and morals of students. This reinforces Roqib's research (Roqib, 2011).

There are 5 models of character education, namely social social education, inclusivemulticultural prophetic education, integrative-interconnective education, prophetic education based on creative-motion philosophy, and edutainment plus education (Roqib, 2011). Whereas in MMA it is categorized as an integrative-interconnective model. Given the absence of dichotomy in subjects in MMA (Zainiyati, 2015; Zainiyati, 2014; \& Ismail, 2013).

The implementation of character education in the Madrasah Muallimin Muallimat 6-year Bahrul Ulum Tambakberas Jombang is indeed attached to the identity of the madrasah. This has been instilled into a culture since the MMA was established. Formation of character has indeed become a habit in madrasah. This certainly undermines Darmayanti and Wibowo and Pala's research which states that character education culture is formed and must be grown in the mindset of all elements in the school, starting from the curriculum to school culture (Darmayanti \& Wibowo, 2014; Aynur, 2011). This madrasah is capable maintain the culture because the leader always gives an overview of madrasah culture. This was also done by the previous leader. So that the culture remains attached to the madrasah and has never been eroded by time. So that the environment with a strong character has been formed as the identity of Madrasah, as well as Lickona's theory in Hulawa which states that the environment is an important factor in character formation (Hulawa, 2018).

The prophetic education practice that has been described above certainly has an impact on the character of students. Among these 6 characters are care, responsibility, perseverance, courage, integrity and discipline. From the implementation in the field, there are unique findings found by researchers. That the implementation of prophetic education in addition has 
been applied in every component of education, it has also been attached to and become a culture owned by Madrasah. In fact, the culture has indeed been held by the founder to be the Madrasah identity. Therefore, the character formed in this Madrasah is very strong. As in the chart as follows:

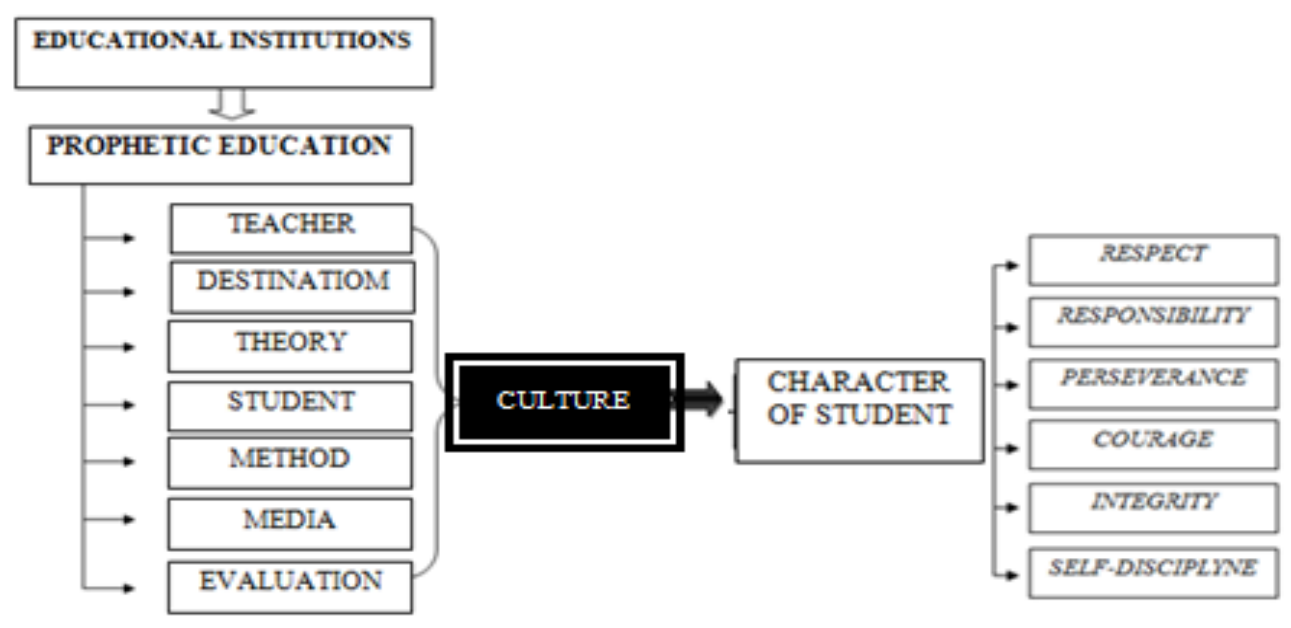

Figure 2. Finding Character Building through Prophetic Education

\section{CONCLUSION}

Moral degradation has penetrated the education sector. Moral defects experienced by the nation certainly do not escape from the responsibility of education. For this reason, it is necessary to return to the Prophet education era. By using prophetic education as a construction in realizing character building, it will certainly be able to answer the current educational problems. Because character is formed through education which not only prioritizes the transfer of knowledge alone but also prioritizes the inculcation of values. This prophetic paradigm must be applied universally to the education component. Not only in formal reason, but prophetic paradigm must be used as culture and habits in Madrasa. In this way a strong character will be formed which will shape the student's personality. This study complements several studies on character education and prophetic education that have been widely reviewed. However, the discussion of the impact on characters seems to be still not comprehensive. So that it can be continued by further researchers.

\section{BIBLIOGRAPHY}

Al Mahalli, J. bin A., \& As Suyuthi, J. A. bin A. B. (2007). Tafsir Jalalain Juz II. Al Haromain. Ambarawati, D. (2019). Kasus AU, Cerminan Bobroknya Moral Generasi. Republika.co.id, Retrieved from https://republika.co.id/berita/ppsj1g349/kasus-ay-cerminanbobroknya-moral-generasi.

Arifuddin. (2019). Konsep Pendidikan Profetik. Jurnal Mudarrisuna, 9(2). http://dx.doi.org/10.22373/jm.v9i2.4782

Asbari, M., Nurhayati, W., Purwanto, A., \& Putra, F. (2020). Pengaruh Genetic Personality Dan Authoritative Parenting Style Terhadap Pendidikan Karakter Di Aya Sophia Islamic School. Edumaspul, 4(1). https://doi.org/10.33487/edumaspul.v4i1.341

Aynur, P. (2011). The Need for Character Education. International Journal of Social Sciences and Humanity Studies, 3(2). Retrieved https://dergipark.org.tr/en/pub/ijsshs/issue/26222/276136

Azra, A. (2012). Pendidikan Islam. Kencana Prenada Media Group. 
Badan Pusat Statistik. (2019). Statistik Kriminal 2019. bps.go.id, Retrieved from https://www.bps.go.id/publication/2019/12/12/66c0114edb7517a33063871f/statisti k-kriminal-2019.html.

Bima, P. (2020). Keluarga NF Siswi SMP yang Bunuh Anak Kecil Dikabarkan Diusir dari Desa, Para Tetangga Trauma. Tribunnews, Retrieved from https://newsmaker.tribunnews.com/2020/03/10/keluarga-nf-siswi-smp-yang-bunuhanak-kecil-dikabarkan-diusir-dari-desa-para-tetangga-trauma?page $=4$.

Cahyo, E. D. (2017). Pendidikan Karakter Guna Menanggulangi Dekadensi Moral yang Terjadi Pada Siswa Sekolah Dasar. Edu Humaniora: Jurnal Pendidikan Dasar, 9(1).

Cohen, L., Manion, L., \& Marrison, K. (2007). Research Methods in Education. Routledge.

Darmayanti, S. E., \& Wibowo, U. B. (2014). Evaluasi Program Pendidikan Karakter Di Sekolah Dasar Kabupaten Kulon Progo. Jurnal Prima Edukasia, 2(2). https://doi.org/10.21831/jpe.v2i2.2721

Diniaty, A. (2013). Urgensi Teori Konseling Dan Perspektifnya Dalam Islam Menjawab Tuntutan Konseling Religius Di Masa Depan. Jurnal Al-Ta'lim, 1(4). Retrieved from https://journal.tarbiyahiainib.ac.id/index.php/attalim/article/view/27

Frye, M., Lee, A. R., \& LeGette, H. (2002). Character Education. Public Schools of North Carolina.

Hakim, D. M. (2017). Implementasi Pendidikan Profetik di Madrasah Tsanawiyah. VICRATINA: Jurnal Pendidikan Islam, 2 (2). Retrieved from http://riset.unisma.ac.id/index.php/fai/article/view/4874

Hulawa, D. E. (2018). Al-Zarnuji's Character Concept in Strengthening Character Education in Indonesia. Jurnal Pendidikan Islam, 4(2). https://doi.org/10.15575/jpi.v4i2.2395

Ismail, I. I. (t.t.). Ta'lim Muta'allim. Nurul Huda.

Idrus, M. (2009). Metode Penelitian Ilmu Sosial Jakarta: Erlangga, 2009. Erlangga.

Ismail, S. G. (2013). Implementasi Pendidikan Profetik Dalam Pembelajaran Pendidikan Agama Islam.". Mudarrisa: Jurnal Kajian Pendidikan Islam, 05(02). https://doi.org/10.18326/mdr.v5i2.299-324

Kuntowijoyo. (2007). Islam Sebagai Imu. Tiara Wacana.

Ma'rufah, N., Rahmat, H. K., \& Widana, I. (2020). Degradasi Moral Sebagai Dampak Kejahatan Siber Pada Generasi Millenial di Indonesia. Nusantara: Jurnal Ilmu Pengetabuan Sosial, 7(I). http://dx.doi.org/10.31604/jips.v7i1.2020.191-201

Meindl, P., Quirk, A., \& Graham, J. (2018). Best Practices for School-Based Moral Education. Policy Insights from the Behavioral and Brain Sciences, 5(1). https:/ / doi.org/10.1177/2372732217747087

Nizar, S. (2007). Sejarah Pendidikan Islam. Kencana Prenada Media Grup.

Purwanto, N. (1991). Ilmu Pendidikan Teoritis dan Praktis. PT Remaja Rosdakarya.

Roqib, M. (2011). Prophetic Education: Kontekstualisasi Filsafat dan Budaya Profetik dalam Pendidikan. STAIN Press.

Setiawan, D. (2013). Peran Pendidikan Karakter dalam Mengembangkan Kecerdasan Moral. Jurnal Pendidikan Karakter, 3(1). https://doi.org/10.21831/jpk.v0i1.1287

Shofan, M. (2004). Pendidikan Berparadigma Profetik. IRCiSoD.

Sugiyono. (2015). Metode Pendidikan pendekatan Kuantitaif, kualitatif, dan R\&D. Alfabeta.

Suharto, T. (2011). Filsafat Pendidikan Islam. Ar Ruzz Media.

Wahidin, U., \& Syaefuddin, A. (2018). Media Pendidikan dalam Perspektif Pendidikan Islam. Jurnal Edukasi Islami: Jurnal Pendidikan Islam, 7(1). http://dx.doi.org/10.30868/ei.v7i01.222 
Watson, L. (2019). Educating for inquisitiveness: A Case against Exemplarism for Intellectual Character Education. Journal of Moral Education. 48 (3). Retrieved from https://www.tandfonline.com/doi/abs/10.1080/03057240.2019.1589436? src=recsys \&journalCode $=$ cjme 20

Zadjuli, S. I. (2007). Reformasi Ilmu Pengetahuan dan Pembangunan Masyarakat Madani di Indonesia. Journal of Islamic Business and Economics, 1(1).

Zainiyati, H. S. (2014). Model Kurikulum Integratif PesantrenMahasiswa Dan Uin Maliki Malang. Ulumuna: Jurnal Studi Keislaman, 18(1). https://doi.org/10.20414/ujis.v18i1.156

Zainiyati, H. S. (2015). Landasan Fondasional Integrasi Keilmuan Di UIN UIN Maulana Malik Ibrahim Malang Dan UIN Sunan Ampel Surabaya. Islamica: Jurnal Studi Keislaman, 10(1). https://doi.org/10.15642/islamica.2015.10.1.248-276

Zurqoni, Retnawati, H., Arlinwibowo, J., \& Apino, E. (2018). Strategy and Implementation of Character Education in Senior High Schools and Vocational High Schools. Journal of Social Studies Education Research, 9(3). Retrieved from https://jsser.org/index.php/jsser/article/view/294 